\title{
Mi a szabadság?
}

\section{A Biblia és az alkotmányjog szabadságfogalmának hasonlósága és különbözősége}

\section{CSINK LÓRÁNT ${ }^{1}$}

\begin{abstract}
A keresztény szabadság és liberális szabadság szembeállitása a közéleti viták egy népszerü témaköre. A tanulmány e vitának egy részéhez szól hozzá; a keresztény szabadságot az alapján közelíti meg, hogy a keresztény vallás alapja, a Biblia mit tanit a szabadságról, a liberális szabadságot pedig a klasszikus liberális gondolkodók szemüvegén keresztül láttatja.

A tanulmány nem képes és nem is hivatott teljességében bemutatni sem a liberalizmust, még kevésbé pedig a Biblia világ-és emberképét. Célja nem más, mint a szabadság tartalmának, forrásának és céljának az összehasonlitása.
\end{abstract}

Kulcsszavak: szabadság, liberalizmus, alkotmányos alapok, Biblia

\author{
What Is Liberty? \\ Liberty in the Context of Constitutional Law and the Bible - Similarities \\ and Differences
}

Comparing Christian liberty and classic liberalism is a popular issue of public debates. The paper considers only one part of the topic; it analyses Christian liberty from the viewpoint of the Bible and constitutional liberty in the aspect of classical liberal doctrines.

The paper cannot and will not present either the liberal or the biblical standpoint of human nature in its entirety. It only aims at comparing the source, the content and the target of liberty.

Keywords: liberty, liberalism, constitutional fundaments, Bible

A szabadság a jognak is, és a teológiának is az egyik alapfogalma, ráadásul egy olyan fogalom, amelynek köznapi jelentése is van: mindenki tudni véli, mi a szabadság. Rövid átgondolást követően viszont feltűnik a kérdés összetettsége: nemcsak hogy a jog és a teológia számára jelent mást a szabadság, sőt

1 Egyetemi docens, PPKE JÁK; e-mail: csink.lorant@jak.ppke.hu. 
még nem is csak arról van szó, hogy különböző jogágak eltérő értelmet tulajdonítanak a szabadságnak, hanem hogy még jogágon belül sincs egységes értelmezés. A szabadság jellemzően az a fogalom, amit az alkotmányjog a mindennapos működés során használ, de nem definiál.

Elöljáróban le kell szögezni, hogy filozófiai értelemben totális szabadság nem létezik. Az ember nem függetlenítheti magát a gravitáció törvényétől (fizikai korlát), elodázhatja, de nem kerülheti el a meghalást (biológiai korlát) stb. A szabadságot tehát csak a külső tényezők keretei között lehet értelmezni. Ezt annyira természetesnek érezzük, hogy a teljes szabadságot a környezeti keretek közötti teljes szabadságnak tekintjük. A jogban pedig leginkább úgy használjuk a szabadság fogalmát, hogy a tárgyat is meghatározzuk (szabadság valamire) - így sokkal kézzelfoghatóbb, könnyebben kezelhető fogalmat kapunk.

Ez az írás arról szól, hogy a történelem két meghatározó eszmeisége, a Biblia és a liberalizmus miképp áll hozzá a szabadsághoz. Napjainkban népszerủ téma szembeállítani a keresztény szabadságot a liberális szabadsággal. Ennek oka az, hogy az egyes irányzatok képviselői meglehetősen kritikusak a másik szabadságfogalmával szemben, azt nem is tartják igazán szabadságnak. A keresztény szabadság kritikusai a kereszténységet egyáltalán nem szabadságnak, hanem jó szándékú, ámde anakronisztikus erkölcsi szabályoknak való kínos megfelelésnek tartják. A másik oldalról pedig a liberális szabadságot szabadosságnak, erkölcs nélküli elképzelések öncélú megvalósításának tartják.

A jelen írás hipotézise, hogy ez a szembeállítás téves. Úgy vélem, hogy a bibliai értelemben vett, illetve a liberális alapú, alkotmányjogban használt két szabadságfogalom között elsősorban nem tartalmi különbség van, hanem a két szabadság forrása és célja tér el. A hipotézis igazolása céljából elsőként azt vizsgálom, hogy a Biblia milyen szabadságfogalmakat használ, illetve hogy a Biblia szerint honnan ered a szabadság, mi a tartalma és mi a célja. Ezt követően elemzem, hogy az alkotmányjogban használt, a liberalizmus szellemiségében kialakított szabadságfogalomnak mi a jelentéstartalma, majd összevetem a két szabadságfogalmat.

\section{A Biblia szabadságfogalma}

A jelen írás e helyen szándékosan nem keresztény² szabadságról szól. A Biblia nem erkölcsi tanítások gyűjteménye, sokkal inkább szól Istenről, az emberről és kettejük kapcsolatáról, amiből következik ugyan egy keresztény etika, de nem ez a Biblia célja. A Biblia szabadságfogalma nem valamilyen eszme, tan vagy doktrína.

2 Egyes felekezetek váltakozva használják a keresztyén és a keresztény kifejezéseket, előbbit a protestánsok, utóbbit (főleg, de nem kizárólag) a katolikusok. Csak a szóalak különbözik, az eredet nem; mindkét írásmód eredete a görög Khrisztianosz, azaz krisztusi, Krisztushoz hasonló. Mivel általában a világi szóhasználat, így a jog nyelve is a „keresztény” írásmódot használja, ez az írás is így tesz róla említést. 
A Biblia (legalább) két értelemben beszél a szabadságról. Az egyik lehetséges értelmezése a szabadságnak a Biblia szellemében a szabad akarat, azaz hogy szabadon dönthet az ember Isten mellett vagy ellen. (Fontos, de a jelen írás tárgyához nem tartozó kérdés, hogy a Biblia értelmében harmadik út nincsen.) A szabadságnak ez az értelme jelenik meg Mózes ötödik könyvében, a Deuteronomiumban: „Tanúul hívom ma ellenetek az eget és a földet, hogy előtökbe adtam az életet és a halált, az áldást és az átkot. Válaszd hát az életet, hogy élhess te és utódaid is!" ${ }^{3} \mathrm{Az}$ igehelyet megelőzően Isten leírja, hogy milyen áldásokra számíthat a választott nép, ha tanítását, parancsait megtartja, továbbá hogy milyen átkokkal kell számolnia akkor, ha azokat elutasítja. A döntés szabadsága viszont adott: Isten nem kényszerítette népét arra, hogy mellette döntsön. Más kérdés, hogy az ember döntésének következménye van.

A szabadság egyik megjelenési formája tehát, hogy a Bibliából nem vezethető le univerzális, mindenki számára kötelező parancs arra nézve, hogy Isten fennhatósága alatt kell élni. Még ha a kereszténység egy időben erről eltérően is vélekedett, a Biblia csak felajánlja az Isten szövetségébe való bekerülést - a szabadság abban áll, hogy ennek elfogadásáról vagy elutasításáról mindenki szabadon dönthet.

A szabadság egy másik, a téma szempontjából még fontosabb aspektusa a hívő ember szabadsága, azaz hogy mit mond a Biblia arról, hogy mit tehetnek meg azok, akik már Isten mellett döntöttek. Ennek részletesebb elemzése előtt érdemes megvizsgálni, mit mond Jézus a szabadságról János evangéliumában:

„Így szólt akkor Jézus azokhoz a zsidókhoz, akik hittek benne: Ha ti megtartjátok az én igémet, valóban tanítványaim vagytok; megismeritek az igazságot, és az igazság megszabadít titeket. Ök ezt kérdezték tőle: Âbrahám utódai vagyunk, és soha nem voltunk szolgái senkinek: hogyan mondhatod hát, hogy szabadokká lesztek? Jézus így válaszolt nekik: Bizony, bizony, mondom néktek, hogy aki bűnt cselekszik, a bün szolgája. A szolga pedig nem marad a házban örökre: a fiú marad ott örökre. Ha tehát a Fiú megszabadít titeket, valóban szabadok lesztek."

Ebben a kiragadott részben Jézus nem az emberiséghez szól, még csak nem is általában a zsidósághoz, hanem csak azokhoz a zsidókhoz, akik hittek benne (azaz akik az előző értelemben vett szabadságuk alapján mellette döntöttek). Önekik mondja Jézus, hogy „az igazság megszabadít titeket”, amin ők megütköznek, mondván, hogy „soha nem voltunk szolgái senkinek". Ebben a párbeszédben Jézus hallgatói a szabadságot a rabság hiányával azonosítják, amire Jézus azzal válaszol, hogy aki bűnt cselekszik, szolgája a bűnnek. A szabadsághoz pedig a „Fiú megszabadítása” (azaz isteni személy közreműködése) szükséges.

A szabadság tehát - eme igehely alapján - nem cselekvési, választási lehetőséget jelent, hanem egy állapotot. Ez az állapot kihat a cselekvési lehetőségekre, de nem

3 5Móz 30,19. Az igehelyek hivatkozásánál a Magyar Bibliatársulat kiadását (Budapest, Kálvin János Kiadó, 2008) használom.

$4 . \quad$ Jn 8,31-36. 
azonos azokkal. Vizsgáljuk meg, hogy ennek a szabadságnak mi a forrása (honnan van a szabadság), mi a tartalma (mire terjed ki a szabadság) és mi a célja (valaminek a használatába állítható-e a szabadság).

Az előbb idézett igehelyből is következik, hogy a bibliai szabadság eredője Isten: az szabad, akit „a Fiú megszabadít”. Másképp megfogalmazva: Ö tud egyedül szabaddá tenni. A Biblia szerint ezt a szabadságot senki más nem tudja megadni, de nem tudja elvenni sem. Jézus élete feláldozása kapcsán fogalmazza meg ezt a szabadságot: „Senki sem veheti el tőlem: én magamtól adom oda. Hatalmam van arra, hogy odaadjam, és hatalmam van arra, hogy ismét visszavegyem."5 A bibliai szabadság első jellemzője tehát, hogy - mivel Istentől ered - független a külső körülményektől. Ez a magyarázat arra, hogy hogyan élvezhették ezt a szabadságot olyanok is, akik rossz körülmények közt voltak: éheztek, megalázottak, üldözöttek voltak, vagy épp börtönben raboskodtak. Ugyan a cselekvési lehetőségük igenis korlátozott volt, de ez a szabadság - ahogy arról volt szó - nem cselekvési lehetőség, hanem állapot.

Másodikként, a szabadság tartalma vonatkozásában Pál apostol szavai irányadók: „Minden szabad, de nem minden használ. Minden szabad, de nem minden épít." Vagy ahogy később írja: „Minden szabad nekem, de nem minden használ. Minden szabad nekem, de nem válok semminek a rabjává."7 Ez összhangban van azzal, hogy: „Mindent megpróbáljatok; a mi jó, azt megtartsátok!"8 A szabadság nem uniformizál, hívők is gondolkodhatnak különbözőképp, képviselhetnek eltérő nézeteket, álláspontokat stb. A jogi nyelvben használt megfogalmazással: a bibliai szabadság (is) egyéni cselekvési autonómiát ad.

A szabadság tartalmát nem kötik külső tényezők: a szabadság nem külső parancsoknak való megfelelést jelent. Ami viszont köti a szabadságot, az a célja. A Biblia egyik legfontosabb gondolata, hogy a szabadság nem öncélú. A számos igevers közül csak néhányat idézek itt: Pál apostol a galatabeliekhez írott levelében ezt mondja: „Mert ti testvéreim szabadságra vagytok elhíva; csak a szabadság nehogy ürügy legyen a testnek, hanem szeretetben szolgáljatok egymásnak." A látszólagos ellentétet, miszerint a szabadság arra szolgál, hogy másnak szolgáljunk, a következő igehely megértése esetén tudjuk feloldani: „Mert közülünk senki sem él önmagának, és senki sem hal önmagának; mert ha élünk, az Úrnak élünk, ha meghalunk, az Úrnak halunk meg. Tehát akár élünk, akár meghalunk, az Úréi vagyunk."10 Mivel a hívő ember nem önmagának él, ezért a szabadságát sem saját belátása szerint használja, hanem arra, hogy Istent dicsőítse és embertársait segítse. A szabadság célja tehát Isten tervének megvalósítása az egyén életében, és ez egészen más, mint a vallási parancsoknak való megfelelés.

\footnotetext{
Jn 10,18 .

1 Kor 10,23 .

1 Kor 6,12.

1Thessz 5,12.

Gal 5,13.

10 Róm $14,7-8$.
} 
A Biblia szabadságfogalmát összegezve a következőket állapíthatjuk meg: egyfelől a Biblia szabadságot ad az embernek arra, hogy döntsön Isten mellett vagy ellen, másfelől a Biblia beszél a hívő ember életének szabadságáról, amely 1. nem cselekvési lehetőséget, hanem állapotot jelent; 2. független a külső körülményektől; 3. tartalmát tekintve korlátlan, de 4 . célhoz kötött: a szabadság gyakorlását Isten céljainak kell alárendelni.

\section{Szabadság a liberális (alkotmány)jogban}

Ahogy a Bibliában, az alkotmányjogban is többféle szabadságfogalom létezik. Hozzá kell tenni azt is, hogy a liberalizmus nem kizárólagos irányzata az alkotmányjogi szabadságnak; versengő irányzatként a természetjogot szokás megjelölni, amely a szabadság és a felelősség kapcsolatára helyezi a hangsúlyt. ${ }^{11} \mathrm{~A}$ jelen írás témája azonban a liberális szabadság és a bibliai szabadság összevetése, ezért a továbbiakban azt elemzem.

Nem csupán a szabadságot kell magyarázni, hanem a jelzője, a liberális is értelmezésre szorul. Ezt a problémát veti fel Ronald Dworkin, aki leírja, hogy az 1960-1970-es évekig a liberalizmust a vallott nézetekről lehetett megismerni: az volt liberális, aki és ami a nagyobb gazdasági egyenlőséget, a globalizmust, a szólásszabadságot és a cenzúra eltörlését, a faji szegregáció eltörlését, az Egyház és az állam minél élesebb elválasztását, a büntetőeljárás alá vont terheltek számára erős eljárási garanciákat és egyes „erkölcsös” bűncselekmények (például kábítószerrel visszaélés) dekriminalizációját követelte. Dworkin a brit és az amerikai tapasztalatok alapján arra következtetett, hogy a vietnámi háborút követően a klasszikus liberális-konzervatív törésvonal megszűnt, mivel egyre több ügy merül fel, aminek támogatása vagy elutasítása nem ezen a megosztáson alapul. ${ }^{12}$

Ebben az írásban azt a felfogást nevezem liberális szabadságnak, amelyik a társadalom középpontjába az egyént helyezi, az individuumból kiindulva kívánja megérteni az egyén és a társadalom szerepét. Ez a választás önkényes, és nem is feltétlenül azonos a mai politikai kommunikációban liberálisnak számító felfogással. Azért tekintem mégis ezt a (jogi értelemben vett) szabadság kiindulópontjának, mert ez az eszmeiség volt az, amely a 18. században az abszolutizmus helyébe lépő paradigmaváltást eredményezte: nem az ember van az államért, hanem az állam az emberért. Ahogy azt 1776-ban az amerikai Függetlenségi nyilatkozat megfogalmazta:

„Magától értetődőnek tartjuk azokat az igazságokat, hogy minden ember egyenlőként teremtetett, az embert Teremtője olyan elidegeníthetetlen Jogokkal ruházta fel, amelyekről le nem mondhat, s ezek közé a jogok közé tartozik a jog az Élethez és a Szabadsághoz, valamint a jog a Boldogságra való törekvésre. Ezeknek

11 Erdő Péter: Szabadság és jog keresztény szemmel. In Gudrun Kugler - Pásztor Péter (szerk.): Szabadság és hit. Budapest, Polgári Magyarországért Alapítvány, 2012. 14.

12 Ronald Dworkin: A Matter of Principle. Cambridge, Harvard University Press, 1985. 181. 
a jogoknak a biztosítására az Emberek Kormányzatokat létesítenek, amelyeknek törvényes hatalma a kormányzottak beleegyezésén nyugszik. Ha bármikor, bármely Kormányforma alkalmatlanná válik e célok megvalósítására, a nép Joga, hogy az ilyen kormányzatot megváltoztassa vagy eltörölje, és új Kormányzatot létesítsen, olyan elvekre alapítva és hatalmát olyan módon szervezve, amely jobban védi Biztonságát, és jobban elősegíti Boldogulását."13

Azaz az államnak kell szolgálnia az egyént és az egyén szabadságát, és ha e kötelezettségének az állam nem tesz eleget, a kormányzat leváltható.

Az alkotmányjog a szabadságot használja társadalmi-politikai értelemben, illetve beszél az egyéni szabadságról. A társadalmi-politikai szabadság a zsarnoki rendszerek, diktatúrák ellentéte. Az a társadalom szabad, ahol nincs elnyomás. A szabadság ebben az értelemben egy politikai program, megvalósítandó cél is. A politikai szabadság természetesen összefügg az egyéni szabadsággal, de az egyén szabadságát a politikai közösség autonómiája önmagában nem biztosítja. ${ }^{14}$ Általánosságban kijelenthető, hogy az egyes emberek szabadabbak demokráciában, mint diktatúrában. Teljes fedésben viszont nincs a két fogalom: egy demokráciában sem jelenthető ki, hogy mindenki tényleg szabadon él. A politikai szabadság nem korlátlan szabadság, hanem a tömegek által garantált szabadság. ${ }^{15}$

Az egyéni szabadság fogalmára a jogelmélet több meghatározást is adott. Thomas Hobbes szerint „[s]zabadságon a szó eredeti értelmében a külső akadályok távollétét értjük. Ezek az akadályok gyakran elvonják az ember erejének egy részét attól, amit tenni szeretne, azt azonban nem gátolhatják meg, hogy ereje megmaradó részét megítélésének és értelmének parancsa szerint használja fel." ${ }^{16}$ Hobbes megközelítésében a szabadság külső tényezők függvénye. Ha a külső akadályok „távol vannak” (nincsenek), akkor van szabadság, míg a külső akadályok közelsége esetén nincsen. A szabadság tartalma pedig az, hogy az ember megtehesse, amit tenni szeretne, még ha teljesen nem is tudja megvalósítani a külső akadályok miatt.

Lényegében hasonló álláspontra helyezkedett Immanuel Kant: „[A] szabadság a mások önkényes kényszerítésétől való függetlenség."17 Ebben a megközelítésben is külső tényezők függvénye a szabadság: az ember akkor szabad, ha függetleníteni tudja magát mások önkényes kényszerítésétől, egyszerübben: nem kényszeríthetik olyanra, amit nem akar. Nézzük meg e szabadságfogalom kapcsán is, hogy mi az eredője, a tartalma és a célja. John Locke szerint a szabadság és az egyenlőség az ember természeti állapota. ${ }^{18} \mathrm{~A}$ szabadság azonban nem abszolút, ugyanis érvényesülése külső tényezők-

13 Vecseklőy József fordítása.

14 Bragyova András: Alkotmány és szabadság. Fundamentum, 7. (2003), 3-4. 5.

15 Halmai Gábor - Tóth Gábor Attila: Az emberi jogok eredete. In Halmai Gábor - Tóth Gábor Attila (szerk.): Emberi jogok. Budapest, Osiris, 2003. 39.

16 Thomas Hobbes: Leviatán. Budapest, Magyar Helikon, 1970. 1. kötet, 171.

17 Immanuel Kantot idézi Bragyova i. m. (14. lj.) 5.

18 John Locke: Értekezés a polgári kormányzat igazi eredetéröl, hatásköréről és céljáról. Budapest, Gondolat, 1986. 41. 
től függ; a szabadságból áldozni kell további értékek érvényesülése érdekében. Ilyen további érték Hobbesnál a biztonság, Dworkinnál az egyenlőség.

A szabadság és biztonság kapcsolatáról Hobbesnak az volt a véleménye, hogy a bellum omnium contra omnes állapotában az egyén korlátlan szabadsága végső soron a kiszolgáltatottságához vezet - mások korlátlan szabadsága folytán veszélybe kerül saját javainak és személyes integritásának a megtartása. ${ }^{19}$ Alapvető igény volt tehát, hogy a hatalom teremtsen rendet és kiszámíthatóságot, védje meg az emberek tulajdonát és személyét, azaz adjon biztonságot. Ebben a megközelítésben a biztonság igen összetett és sokrétủ fogalom, beletartozik egyfelől mindaz a védelem, amely a személy, illetve a tulajdon elleni támadás elhárítását szolgálja, másfelől pedig az a komfortérzet is, hogy az egyénnek ilyen támadásra nem is kell okkal számítania. ${ }^{20} \mathrm{~A}$ gyakorlatban is az látható, hogy az egyén minél inkább fenyegetve látja a biztonságát, annál többet hajlandó áldozni szabadságából, és fordítva: minél inkább hiányzik a szabadsága, annál többet kockáztat, azaz áldoz a biztonságából. Hobbes gondolatmenetében biztonság nélkül nincs szabadság, ehhez pedig hozzá lehet tenni, hogy szabadság nélkül létezhet ugyan biztonság, de értelmetlen: nem valósítja meg az egyén természeti állapotát. ${ }^{21}$

A szabadság és a biztonság konfliktusa mellett az is egyértelmúvé vált, hogy a francia forradalom szabadság, egyenlőség és testvériség jelszavai közül az első kettő nem élhet egymás mellett abszolút módon: a két elv konkurál egymással. Ahogy arról Dworkin ír: „Sajnos szabadság és egyenlőség gyakran ütköznek: néha az egyetlen hatékony eszköz az egyenlőség előmozdítására szükségessé teszi a szabadság néminemủ korlátozását, és néha a szabadság előmozdításának következményei hátrányosak az egyenlőségre nézve."22 Az látható tehát, hogy a szabadság forrása (eredője) az ember természeti állapota, azaz az ember eredendően szabad. Szabadságát viszont csak megfelelő külső körülmények fennállta esetén tudja gyakorolni.

E szabadság tartalmát tekintve az egyéni cselekvési autonómiát jelenti. Az individuális szabadság az önálló magatartás szabadsága, ${ }^{23}$ és a liberális felfogás szerint az egyén szabadsága az állam első, de nem egyetlen célja. ${ }^{24}$ Bragyova András azt is hozzáteszi, hogy negatív értelemben a szabadság a korlátozás hiányát, pozitív értelemben pedig meghatározott cselekvési lehetőség biztosítását jelenti. ${ }^{25} \mathrm{~A}$ cselekvési autonómia alapján az egyén szabadon eldöntheti, hogy milyen magatartást tanúsít, milyen álláspontot alakít ki, hogyan él, stb. Az egyéni cselekvési autonómia - nem

19 Vö. Hobbes i. m. (16. lj.) 206-208.

20 Nem beszélhetünk ugyanis biztonságról, ha az egyén állandó rettegésben él, hogy tulajdona, testi épsége veszélyben van, még abban az esetben sem, ha az ezek elleni támadás végül nem következik be.

21 Megszívlelendő Benjamin Franklin gyakran idézett mondata is: „Aki a rövid távú biztonság érdekében feláldozza a hosszú távú szabadságot, nem érdemli meg sem a biztonságot, sem a szabadságot.”

22 Dworkin i. m. (12. lj.) 188.

23 Bragyova i. m. (14. lj.) 12.

24 Uo. 5.

25 Uo. 12. 
kizárólagosan ugyan - az emberi jogok szabad gyakorlását is jelenti. Ez a szabadság tartalmilag teljes abban az értelemben, hogy csak meghatározott esetekben, mások szabadságának biztosítása vagy egyéb igazolható célok elérése érdekében korlátozható. Bár a szabadság gyakorlása teljesen az egyénre van bízva (ő rendelkezik vele), ez a szabadság mégsem foglalja magában azt a vélekedést, hogy az egyénnek csak saját, személyes érdekeire kell tekintettel lennie szabadsága gyakorlása során. ${ }^{26}$

A „másik figyelembevételének” közgazdasági és erkölcsi igazolása is van. A közgazdasági igazolás értelmében a piaci verseny kifejezetten jót tesz nemcsak a gazdaságnak, hanem a versenyben részt vevőknek is: miközben egymással versenyeznek, nemcsak saját helyzetükön javítanak, hanem hozzájárulnak a versenytárs fejlődéséhez is. Kis János megfogalmazásában az emberek úgy tudják a mások javát szolgálni, ha engedik őket a saját hasznukat követni. ${ }^{27}$ Közgazdasági szakkifejezéssel élve a vegyes motivációjú játékok jellemzőn nem zéró összegűek, a játékosok nem csak egymástól nyerhetnek vagy veszthetnek, és sok esetben a versengés a legjobb módszer arra, hogy eredményes kooperáció alakuljon ki. ${ }^{28}$

A liberális szabadság erkölcsi igazolása azt jelenti, hogy a szabadság nem jelent teljes szabadosságot, a javak öncélú élvezetét. A liberális gondolkodásmódban fontos szerepet játszik az erkölcs: a tanúsított magatartásokat az erkölcsi mércéhez kell viszonyítani. Az erkölcs persze nem a liberalizmus sajátja: már Szent Ágoston megjegyezte, hogy „mi mások lennének az államok igazságosság nélkül, mint hatalmas rablóbandák?" 29 A liberális felfogás ugyanakkor a morált közvetlenül az alkotmányjoghoz kapcsolja; „a morális értelmezés [...] a politikai erkölcsöt az alkotmányjog szívébe helyezi" ${ }^{30}$ Ez az alapjogi koncepció a jog súlypontját az alkotmányos alapjogok köré telepíti, ennek kritikájaként van olyan vélemény, amely szerint a jogrendszer közvetlen átmoralizálása tönkreteszi a jogot. ${ }^{31}$

A liberális felfogás tehát nem veti el az erkölcsöt, sőt a cselekedetek mércéjévé teszi. Ez az erkölcs univerzális abban az értelemben, hogy általánosságban, absztrakt szinten közmegegyezés alakítható ki arról, hogy mi erkölcsös, és mi nem, és ebböl következően arról is, hogy milyen magatartás tanúsítása helyeselhetö, és milyen nem (például a békére törekvés erény, a háborúság nem, a türelem erény, a türelmetlenség nem, a szeretet erény, a gyülölet nem, stb.). Azonban az univerzális erkölcs nem minden esetben ad segítséget a konkrét élethelyzet erkölcsiségének objektív megítéléséhez. Könnyen előfordulhat, hogy például mindkét háborúzó fél a másikat okolja a háborúskodásért, vagy házasfelek egymást a kapcsolat megromlásáért. Ilyen esetekben

26 Kis János: Az állam semlegessége. Budapest, Atlantisz, 1997. 191.

27 Uo. 191-192.

28 Mérő László: Mindenki másképp egyforma. A játékelmélet és a racionalitás pszichológiája. Budapest, Tericum, 1996. 145. és 149.

29 Aurelius Augustinus: A pogányok ellen Isten városáról írt huszonkét könyve. Budapest, Dunántúl Pécsi Egyetemi Könyvkiadó és Nyomda, 1942. 238.

30 Ronald Dworkin: Freedom's Law. The Moral Reading of the American Constitution. Cambridge, Harvard University Press, 1996. 2.

31 Pokol Béla: Jogbölcseleti vizsgálódások. Budapest, Nemzeti Tankönyvkiadó, 1994. 8. 
a magatartás mércéje nem az univerzális erkölcs, hanem mindenkinek a saját erkölcsi meggyőződése lesz, azaz végső soron saját maguknak állapítják meg azt az erkölcsi mércét, amelyhez cselekedeteiket elvi szinten igazítják.

\section{A bibliai és a liberális szabadság összevetése}

A Biblia szabadsága és a liberális szabadság jellemzőinek vizsgálatát követően a következő összehasonlítást tehetjük.

A liberalizmus szerint az ember eredendően szabad, és ezt a szabadságát meg is őrizte, azaz képes arra, hogy szabadon éljen. A Biblia szerint ugyan az ember eredendően szabad volt (Isten szabadnak teremtette), de ezt a szabadságát a bủnesettel elveszítette, így jelenleg nem képes arra, hogy szabadon éljen.

- Az előző pontból okszerűen következik, hogy a liberalizmus szerint a szabadság forrása maga az emberi természet. A Biblia szerint a szabadság eredője, forrása Isten; az szabad, akit a Fiú megszabadít.

- A liberalizmus szerint a szabadság gyakorolhatósága függ a külső körülményektől (önkényes behatások, biztonság, egyenlőség stb.), a Biblia szerint a szabadság a külső körülményektől független.

- A szabadság tartalma tekintetében mind a liberalizmus, mind a Biblia szerint a szabadság az egyéni meggyőződésből eredő magatartás tanúsítására ad lehetőséget.

- A liberalizmus szerint a szabadság gyakorlásának mércéje az erkölcs, célja az egyéni érdek megvalósítása, a Biblia szerint a szabadság célja Isten akaratának a betöltése.

- A különbségeket és a hasonlóságokat az alábbi táblázat foglalja össze.

1. táblázat: A Biblia és a liberalizmus szabadságfogalma

\begin{tabular}{|l|c|c|}
\hline & Liberalizmus & Biblia \\
\hline Az ember eredeti állapota & szabad & szabad, de szabadságát elvesztette \\
\hline A szabadság forrása & emberi természet & Isten \\
\hline Körülményektöl való függés & függ & független \\
\hline Tartalom & magatartás tanúsítása & magatartás tanúsítása \\
\hline Cél vagy mérce & erkölcs & isteni akarat \\
\hline
\end{tabular}

Forrás: a szerző szerkesztése

Ez a tanulmány a bibliai értelemben vett szabadság és a liberális szabadság közti különbség elemzésével kívánt hozzájárulni a keresztény szabadság - liberális szabadság témakörének elemzéséhez. Az írás csupán arra mutatott rá, hogy a Biblia szabadságképe más szemléletmódot ad, mint az alkotmányjog egyik meghatározó irányzata. Mindebből nem következik a liberalizmus helyessége vagy helytelensége, és az sem, hogy bibliai alapon az alkotmányjogot a liberalizmustól eltérő irányzatra kellene 
alapítani. A Biblia nem használható egyetlen irányzat igazolására sem, és végképp nem politikai irányzatéra.

\section{Irodalomjegyzék}

Augustinus, Aurelius: A pogányok ellen Isten városáról írt huszonkét könyve. Budapest, Dunántúl Pécsi Egyetemi Könyvkiadó és Nyomda, 1942.

Bragyova András: Alkotmány és szabadság. Fundamentum, 7. (2003), 3-4. 5-24.

Dworkin, Ronald: A Matter of Principle. Cambridge, Harvard University Press, 1985.

Dworkin, Ronald: Freedom's Law. The Moral Reading of the American Constitution. Cambridge, Harvard University Press, 1996.

Erdő Péter: Szabadság és jog keresztény szemmel. In Kugler, Gudrun - Pásztor Péter (szerk.): Szabadság és hit. Budapest, Polgári Magyarországért Alapítvány, 2012.

Halmai Gábor - Tóth Gábor Attila: Az emberi jogok eredete. In Halmai Gábor - Tóth Gábor Attila (szerk.): Emberi jogok. Budapest, Osiris, 2003.

Hobbes, Thomas: Leviatán. Budapest, Magyar Helikon, 1970.

Locke, John: Értekezés a polgári kormányzat igazi eredetéről, hatásköréröl és céljáról. Budapest, Gondolat, 1986.

Kis János: Az állam semlegessége. Budapest, Atlantisz, 1997.

Mérő László: Mindenki másképp egyforma. A játékelmélet és a racionalitás pszichológiája. Budapest, Tericum, 1996.

Pokol Béla: Jogbölcseleti vizsgálódások. Budapest, Nemzeti Tankönyvkiadó, 1994. 